\title{
Udder health of dairy cows fed different dietary energy levels after a short or no dry period without use of dry cow antibiotics
}

\author{
R. J. van Hoeij, ${ }^{11}$ T. J. G. M. Lam,†‡ R. M. Bruckmaier,§ J. Dijkstra,\# G. J. Remmelink,II B. Kemp, ${ }^{*}$ \\ and A. T. M. van Knegsel* \\ *Adaptation Physiology Group, Department of Animal Sciences, Wageningen University and Research, $6700 \mathrm{AH}$, Wageningen, the Netherlands \\ †Department of Farm Animal Health, Utrecht University, 3508 TD, Utrecht, the Netherlands \\ †GD Animal Health, 7400 AA, Deventer, the Netherlands \\ §Veterinary Physiology, Vetsuisse Faculty, University of Bern, CH-3001 Bern, Switzerland \\ \#Animal Nutrition Group, Department of Animal Sciences, and \\ IILivestock Research, Wageningen University and Research, $6700 \mathrm{AH}$, Wageningen, the Netherlands
}

\begin{abstract}
Reports on the effects of length of dry period (DP) on udder health of cows that were not treated with dry cow antibiotics are scarce. Additionally, the effects of a reduced dietary energy level for cows with a 0 -d DP on udder health have not yet been studied. The aims of this study were (1) to compare effects of a 0-d or 30-d DP without use of dry cow antibiotics on udder health across the DP and subsequent lactation in dairy cows fed different dietary energy levels and (2) to evaluate associations between udder health and metabolic status of dairy cows. Five weeks before the expected calving date, Holstein-Friesian dairy cows (n $=115$ ) were blocked for parity, expected calving date, and milk yield and somatic cell count (SCC) at their 2 last test days and were randomly assigned to $2 \mathrm{DP}$ lengths: 0-d DP $(\mathrm{n}=77)$ or 30-d DP $(\mathrm{n}=38)$. Quarter milk samples were taken in wk 5 prepartum and in wk 1 and 5 postpartum. Proportion of quarters with elevated SCC (SCC $\geq 200,000$ cells $/ \mathrm{mL}$ ) and proportion of udder pathogens in quarter milk samples did not differ between DP lengths among weeks. After calving, 102 of these cows were randomly assigned to 3 treatments: a 30-d DP with a standard energy level required for expected milk yield (30-d DP SEL; $\mathrm{n}=36$ ), a 0 -d DP with the same energy level as cows with a 30-d DP (0-d DP SEL; $\mathrm{n}=33$ ), and a 0 -d DP with a low energy level $(0-\mathrm{d}$ DP LEL, $\mathrm{n}=33)$. From wk 8 of lactation onward, cows received either a glucogenic ration consisting of corn silage and grass silage or a lipogenic ration consisting of grass silage and sugar beet pulp at a standard or low energy level. During wk 1 to 7 postpartum, treatment did not affect SCC or SCC cor-
\end{abstract}

Received July 6, 2017.

Accepted December 15, 2017.

${ }^{1}$ Corresponding author: ariette.vanknegsel@wur.nl rected for milk yield. During wk 8 to 44 of lactation, 0-d DP SEL cows had a greater SCC than 0-d DP LEL or 30-d DP SEL cows and had a greater SCC corrected for milk yield than 0-d DP LEL cows. During wk 1 to 44 of lactation, occurrence of at least 1 elevation of SCC (SCC $\geq 200,000$ cells $/ \mathrm{mL}$ after 2 wk of SCC $<200,000$ cells $/ \mathrm{mL}$ ) was not different among treatments. The 0 -d DP SEL cows but not the 0-d DP LEL cows tended to have a 2.17 times greater hazard of having a case of clinical mastitis at any time in lactation than 30-d DP SEL cows. In wk 1 to 44 of lactation, lower fat- and protein- corrected milk yield and energy intake, greater energy balance, and greater plasma insulin concentration were associated with greater SCC. In conclusion, DP length did not affect udder health in the DP and in early lactation but seemed to decrease udder health for 0-d DP SEL cows in later lactation compared with 30-d DP SEL or 0-d DP LEL cows.

Key words: continuous milking, decision making, antibiotic use

\section{INTRODUCTION}

The dry period (DP) is an important period in the dynamics of IMI in dairy cows (Green et al., 2005; Pantoja et al., 2009b; Scherpenzeel et al., 2014). Management of the DP with respect to udder health aims to both cure existing IMI and reduce the risk of new IMI during the DP (Collier et al., 2012). Management measures to reduce the risk of new IMI during the DP include herd-level measures such as housing, hygiene, and nutrition and cow-level measures such as use of dry cow antibiotics or internal teat sealants (Annen et al., 2004; Green et al., 2007). Use of dry cow antibiotics improves the cure rate of existing IMI during a DP (Williamson et al., 1995). However, use of antibiotics may increase bacterial resistance, which raises a hazard for treatment of human and animal bacterial infection 
(van den Bogaard and Stobberingh, 2000; Tenhagen et al., 2006). Preventive use of antibiotics (e.g., dry cow antibiotics in cows without an IMI) is therefore not allowed in several European countries, including the Netherlands, and use of dry cow antibiotics is restricted for treatment of diagnosed IMI based on SCC or bacterial culture (Dutch Ministry of Economic Affairs, 2017).

Shortening or omitting the DP has been hypothesized to affect udder health in dairy cows, although reported effects are ambiguous. Compared with a conventional DP length (49-60 d), a short (28-35 d) or omitted (0 d) DP decreased SCC in the subsequent lactation (Gulay et al., 2003; Pinedo et al., 2011), resulted in no difference in SCC (Rastani et al., 2005; Watters et al., 2008; Bernier-Dodier et al., 2010), or increased SCC (Kuhn et al., 2006; Pezeshki et al., 2007; Steeneveld et al., 2013). A conventional DP length, compared with a short DP, tended to reduce the number of IMI in the subsequent lactation in some studies (Pezeshki et al., 2007; Pinedo et al., 2011), whereas other studies found no effect of shortening (Church et al., 2008; Shoshani et al., 2014; van Hoeij et al., 2016) or omitting (van Hoeij et al., 2016) the DP on clinical mastitis in the subsequent lactation. To our knowledge, all studies on the effect of DP length on udder health have been carried out using cows that were treated with dry cow antibiotics at drying off. Given the changed antibiotic policy in many countries and to study effects of DP length without the confounding effect of dry cow antibiotics, cows were not treated with dry cow antibiotics in the current study.

Metabolic status may negatively affect udder health (Ingvartsen and Moyes, 2013; Mayasari et al., 2016). Increased lipid accumulation in the liver and elevated plasma nonesterified fatty acid concentrations are associated with a greater risk for ketosis (Drackley, 1999). For example, Suthar et al. (2013) reported that cows with subclinical ketosis during the first 2 wk postpartum had a 9.5 times greater odds of developing clinical mastitis during that period than cows without subclinical ketosis. Moreover, Kremer et al. (1993) reported in wk 3 to 6 of lactation that cows that had ketosis postpartum - that is, cows that had elevated concentrations of BHB and free fatty acids (FFA) along with a low plasma glucose concentration - had more severe mastitis, indicated by greater bacterial growth in the quarter inoculated with Escherichia coli, than nonketotic cows. To our knowledge, no studies on direct associations between calculated energy balance (EB) or associated plasma metabolites and udder health in a complete lactation have been undertaken. We hypothesized that cows with a less negative EB would have lower plasma FFA and BHB concentrations and have better udder health than cows with a greater negative EB.
Shortening or omitting the DP improved the metabolic status of dairy cows in early lactation through a reduction in postpartum milk yield compared with a conventional DP of $8 \mathrm{wk}$ (Rastani et al., 2005; van Knegsel et al., 2014). To date, effects of DP length on milk yield and EB in the subsequent lactation have always been evaluated with a lactation ration containing the same energy level for all cows. It is possible that, for cows with no DP, because of their lower postpartum milk yield, feeding a ration lower in dietary energy level throughout lactation or feeding a less glucogenic ration after peak milk yield might reduce the risk of developing excess fat reserves, which is beneficial for herd health and productivity. Recently, we reported that reducing the dietary energy level for cows with 0-d DP reduced the positive EB in wk 6 and 7 of lactation but did not affect milk yield in early lactation compared with cows that received a standard energy level (van Hoeij et al., 2017a). Further research on the effects of DP length and feeding different dietary energy levels on udder health during mid and late lactation is needed.

The first aim of this study was to compare the effect of a $0-d$ or 30-d DP without use of dry cow antibiotics on udder health across the DP and the subsequent lactation (up to $44 \mathrm{wk}$ of lactation). The second aim was to evaluate effects of dietary energy level in wk 4 to 44 of lactation on the udder health of cows with different DP lengths. The third aim was to evaluate associations between metabolic status and udder health of dairy cows.

\section{MATERIALS AND METHODS}

\section{Animals and Housing}

The Institutional Animal Care and Use Committee of Wageningen University and Research (Wageningen, the Netherlands) approved the experimental protocol in compliance with Dutch law on animal experimentation (protocol no. 2014125). The experimental design, DP lengths, and dietary contrasts were described previously (van Hoeij et al., 2017b). For this experiment, cows were selected based on (1) being bred with a Holstein sire, (2) expected calving interval $<490 \mathrm{~d}$, (3) daily milk yield $>16 \mathrm{~kg}$ at $90 \mathrm{~d}$ before the expected calving date, and (4) no clinical mastitis and an SCC $<250,000$ cells/ $\mathrm{mL}$ at the last 2 test days before randomization. Cows were permanently housed in a freestall barn with a slatted floor and cubicles. Dry cows were housed separately from lactating cows. Cows were milked twice daily at approximately 0600 and $1800 \mathrm{~h}$. The experimental period of the current study started in wk 5 prepartum and lasted until wk 44 of lactation. 


\section{Experimental Design}

In total, 130 cows entered the experiment, including 6 cows that entered twice. To obtain a balanced distribution of cows across treatments, groups were made of 3 cows with similar expected calving date, milk yield and SCC at the final 2 test days before randomization, and postpartum parity $(2, \geq 3)$. Within each group of 3 cows, 2 cows were randomly assigned to a DP length of $0 \mathrm{~d}$ and 1 cow was assigned to a DP length of $30 \mathrm{~d}$.

Within the group of cows with a $0-d$ DP, cows were randomly assigned to either a low level of energy in wk 4 to 44 of lactation based on the expected milk yield of cows with a 0-d DP or a standard level of energy in wk 4 to 44 of lactation based on expected milk yield of cows with a 30-d DP (van Knegsel et al., 2014). Cows with a 30-d DP were fed a standard level of energy based on their expected milk yield. This resulted in the following 3 treatments: cows with a $30-\mathrm{d}$ DP and a standard dietary energy level (30-d DP SEL, $\mathrm{n}=36)$, cows with a $0-d$ DP with the same standard dietary energy level as cows with a 30-d DP (0-d DP SEL; n $=33$ ), and cows with a 0-d DP with a low energy level (0-d DP LEL; $n=33$ ). The drying-off protocol for cows with a 30-d DP consisted of a transition to the dry cow ration at $\mathrm{d} 7$ before drying-off and transition to milking once daily at $\mathrm{d} 4$ before drying-off. At dryingoff, no dry cow antibiotics were used.

\section{Rations}

Rations prepartum and in early lactation and evaluation of feed intake and EB have been described in detail by van Hoeij et al. (2017a). Briefly, prepartum, cows with a $0-d$ DP received a lactation ration that consisted of grass silage, corn silage, sugar beet pulp, soybean meal, wheat straw, urea, and vitamins and minerals (6.4 MJ of $\mathrm{NE}_{\mathrm{L}} / \mathrm{kg}$ of $\mathrm{DM}$ ). Lactating cows received $1 \mathrm{~kg} / \mathrm{d}$ of standard concentrate in the milking parlor. Prepartum, cows with a $30-\mathrm{d}$ DP received a ration that consisted of grass silage, corn silage, rapeseed meal, wheat straw, urea, and vitamins and minerals (5.4 MJ of $\mathrm{NE}_{\mathrm{L}} / \mathrm{kg}$ of $\mathrm{DM}$ ).

Postpartum lactation rations were described previously in detail by van Hoeij et al. (2017b). In short, all cows were fed the same lactation basal ration for the first $7 \mathrm{wk}$ in lactation as well as $1 \mathrm{~kg} / \mathrm{d}$ of standard concentrate in the milking parlor. All cows received their experimental concentrate between $10 \mathrm{~d}$ before the expected calving date and wk 31 of lactation. Allowance of experimental concentrate increased by 0.3 $\mathrm{kg} / \mathrm{d}$ from $\mathrm{d} 4$ in lactation onward until the maximum concentrate allowance was reached at d 22 in lactation for cows with a low energy level $(6.7 \mathrm{~kg} / \mathrm{d})$ and at d 28 in lactation for cows with a standard energy level (8.5 $\mathrm{kg} / \mathrm{d}$ ). The standard or low energy level, which was introduced in the allowance of experimental concentrate, was continued in the glucogenic $(\mathbf{G})$ and lipogenic $(\mathbf{L})$ basal rations from wk 8 onward. From wk 8 of lactation onward, cows were randomly assigned to either a $\mathrm{G}$ or an $\mathrm{L}$ basal ration at either a standard or a low dietary energy level. Type of ration was included in the experiment to test effects on lactation persistency (van Hoeij et al., 2017b). Cows had free access to water and the dry cow ration or the lactation basal ration throughout the experiment.

\section{Sampling and Analyses}

Milk Yield, Milk Composition, Clinical Mastitis, Feed Intake, and EB. Milk yield was recorded daily from 5 wk prepartum until 44 wk of lactation. Milk samples for fat, protein, lactose, and SCC analysis (ISO 9622, ISO, 2013; Qlip, Zutphen, the Netherlands) were collected 4 times per week (Tuesday afternoon, Wednesday morning, Wednesday afternoon, and Thursday morning) and were analyzed as a pooled cow-composite sample collected during 2 morning and 2 afternoon milkings per cow per week. Fat- and protein-corrected milk (FPCM) yield was calculated as (CVB, 2011)

$$
\begin{aligned}
& \operatorname{FPCM}(\mathrm{kg} / \mathrm{d})=[(0.337+0.116 \times \text { fat content }(\%) \\
& +0.06 \times \text { protein content }(\%)] \times \text { milk yield }(\mathrm{kg} / \mathrm{d}) .
\end{aligned}
$$

Clinical mastitis cases were diagnosed and treated by the milkers of the research herd. A case of clinical mastitis was defined as a treated case of visibly abnormal milk, changes in the udder due to inflammation, or both. All cows with clinical mastitis were treated with antibiotics according to the herd-specific treatment plan based on severity of disease.

Feed intake and EB were determined as described by van Hoeij et al. (2017b). Briefly, daily individual basal ration intake was measured using roughage intake control troughs and was averaged per week, and concentrate supply was recorded using a computerized feeder. Body weight was recorded daily before each milking and was averaged per week. Energy balance was calculated per week as the difference between $\mathrm{NE}_{\mathrm{L}}$ intake and the $\mathrm{NE}_{\mathrm{L}}$ requirements for maintenance, milk yield, and pregnancy.

Bacterial Culturing. Quarter milk samples for culturing were taken aseptically by trained milkers in wk 5 prepartum and wk 1 and wk 5 postpartum (NMC, 1999). Immediately after collection, the milk samples were frozen at $-20^{\circ} \mathrm{C}$ until processing at the laboratory. 
Table 1. Overview of bacteria cultured in quarter milk samples of cows with a 0- or 30-d dry period in wk 5 prepartum and wk 1 and 5 postpartum

\begin{tabular}{llr}
\hline Classification & Bacteria & No. $(\%)$ \\
\hline Major & Escherichia coli & $3(0.2)$ \\
& Staphylococcus aureus & $40(3.1)$ \\
& Streptococcus agalactiae & $40(3.1)$ \\
& Streptococcus dysgalactiae & $2(0.2)$ \\
Streptococcus uberis & $4(0.3)$ \\
& Acinetobacter spp. & $1(0.1)$ \\
& Q-Hemolytic streptococci & $7(0.5)$ \\
& Bacillus spp. & $19(1.5)$ \\
& Coagulase-negative staphylococci (nonspecified) & $70(5.4)$ \\
& Corynebacterium bovis & $59(4.6)$ \\
& Corynebacterium spp. & $57(4.4)$ \\
& Enterococcus spp. & $2(0.2)$ \\
& Gram-positive cocci & $7(0.5)$ \\
& Moraxella spp. & $1(0.1)$ \\
& Staphylococcus chromogenes & $40(3.1)$ \\
& Staphylococcus epidermidis & $20(1.6)$ \\
& Staphylococcus equorum & $1(0.1)$ \\
& Staphylococcus haemolyticus & $23(1.8)$ \\
Staphylococcus sciuri & $8(0.6)$ \\
Negative culture & Staphylococcus simulans & $2(0.2)$ \\
& Trueperella pyogenes & $2(0.2)$ \\
& Negative bacterial culture & $721(56.1)$ \\
& Contaminated samples & $157(12.2)$ \\
& Total & $1,286(100)$ \\
\hline
\end{tabular}

${ }^{1}$ Samples were considered contaminated when 2 or more colonies of $>2$ different types other than Staphylococcus aureus, Streptococcus agalactiae, or $\alpha$-hemolytic streptococci were present without distinct excess of 1 type of colony.

Processing occurred within 6 mo of collection of the samples. From a total of 1,380 samples (115 cows $\times 4$ quarters $\times 3$ time points), 94 samples were not taken due to a dry cow or dry quarter or were unsuitable for analysis due to abnormal composition.

For bacterial culture, quarter samples were thawed at room temperature and $10 \mu \mathrm{L}$ was streaked onto a $6 \%$ sheep blood agar plate. Plates were incubated at $37^{\circ} \mathrm{C}$, and bacterial growth was assessed after 24 and $48 \mathrm{~h}$ of incubation. A bacterial udder infection was defined as the presence of 1 or more colonies of the same type. Identification of bacterial species was done by inspection of the colony morphology and matrix-assisted laser desorption/ionization time-of-flight (MALDI-TOF) MS using the MALDI Biotyper 3.0 (Bruker Daltonics, Bremen, Germany; Barreiro et al., 2010). Samples were considered contaminated when 2 or more colonies of $>2$ different types other than Staphylococcus aureus, Streptococcus agalactiae, or $\alpha$-hemolytic streptococci were present without distinct excess of 1 type of colony. The proportion of contaminated samples was $12.2 \%$ (157/1,286 analyzed samples). A quarter in which $E$. coli, Strep. agalactiae, Staph. aureus, Streptococcus dysgalactiae, or Streptococcus uberis was cultured was defined as infected with a major udder pathogen, in line with Pantoja et al. (2009a). All other culture-positive quarters, unless considered contaminated, were defined as infected with another udder pathogen (Acinetobacter spp., $\alpha$-hemolytic streptococci, Corynebacterium spp., coagulase-negative staphylococci, Trueperella pyogenes, Bacillus spp., gram-positive cocci, Moraxella spp., Enterococcus spp., Staphylococcus spp. except Staph. aureus). Bacterial results were classified in 3 groups: no growth, major udder pathogens, or other udder pathogens. An overview of frequency of cultured udder pathogens is presented in Table 1.

Blood Collection and Analyses. Blood collection and analyses were described previously by van Hoeij et al. (2017b). In short, blood was collected weekly from calving until wk 10 of lactation and every 2 wk between wk 12 and 44 of lactation. Blood $(10 \mathrm{~mL})$ was collected from the coccygeal vein or artery into evacuated EDTA tubes (Vacuette, Greiner BioOne, Kremsmunster, Austria). Blood was analyzed for plasma FFA, BHB, and glucose concentrations in wk 1 to 7 of lactation and for plasma insulin, IGF-1, and growth hormone (GH) concentration in wk 1 to 44 of lactation.

Data Management. For evaluation of udder health across the DP, 15 of 130 cows were excluded from the data set. Exclusion were due to (1) elevated SCC $>250,000$ cells $/ \mathrm{mL}$ at the last test day before $37 \mathrm{~d}$ prepartum $(\mathrm{n}=8),(2)$ an unplanned DP for cows assigned to a 0 -d DP $(\mathrm{n}=4),(3)$ severe claw problems $(\mathrm{n}=$ $1)$, and (4) acute death peripartum $(\mathrm{n}=2)$. The data 
set for udder health across the DP consisted of data of 115 cows ( 57 with parity 2 and 58 with parity $\geq 3$ ). For evaluation of udder health during the complete subsequent lactation, another 13 cows were excluded from the data set. Exclusions were due to (1) being fed an incorrect concentrate level in wk 4 to 44 of lactation (n $=2)$, (2) stealing from a different group's basal ration $(\mathrm{n}=3)$, and (3) having $<200 \mathrm{~d}$ of milk yield records $(\mathrm{n}=8)$. The complete lactation data set consisted of full lactation data of 102 cows (52 with parity 2 and 50 with parity $\geq 3$ ).

\section{Statistical Analyses}

Statistical analyses were performed using SAS version 9.3 (SAS Institute Inc., 2011). The natural logarithm of SCC (cells $\times 10^{3} / \mathrm{mL}$ ) was used for analyses to approximate normality. Significance of treatment effects was declared at $P<0.05$ and trends at $0.05 \leq P<0.10$.

Occurrence of IMI Across Different DP Lengths. For evaluation of IMI, prepartum and postpartum SCC were compared. For cows with a 0 -d or 30-d DP, the last SCC before the drying-off week for cows with a $30-\mathrm{d}$ DP (median $=-51 \mathrm{~d}$; range $=-66$ to $-37 \mathrm{~d}$ prepartum) was compared with the first SCC postpartum obtained after the first 10 DIM (median $=13$ DIM; range $=10$ to 16 DIM). Somatic cell count was considered elevated when SCC was $\geq 200,000$ cells/ $\mathrm{mL}$ (Schukken et al., 2003). Somatic cell count before and after calving was compared with categorized cows in classes as having a chronically high SCC (SCC $\geq 200,000$ cells $/ \mathrm{mL}$ before and after calving), cured high SCC (SCC $\geq 200,000$ cells/mL before and SCC $<200,000$ cells $/ \mathrm{mL}$ after calving), newly high SCC (SCC $<200,000$ cells $/ \mathrm{mL}$ before and SCC $\geq 200,000$ cells/mL after calving), or no high SCC (SCC <200,000 cells/mL before and after calving).

The difference in incidence of postpartum high SCC (binary; 0 or 1) between different DP lengths was analyzed within cows with low or high SCC before the DP (binary; 0 or 1 ) using a logistic regression model (Model 1; PROC LOGISTIC in SAS 9.3; SAS Institute Inc., 2011).

$$
\operatorname{Logit} P\left(\mathrm{y}_{i j}=1\right)=\alpha+\mathrm{DP}_{i}+\varepsilon_{j}
$$

Model 1 estimates the probability $(P)$ that the $i j$ th observation of postpartum high SCC is 1 . Within observations of prepartum high SCC, chronic high SCC $=1$ and cured high $\mathrm{SCC}=0$. Within observations of prepartum low SCC, new high $\mathrm{SCC}=1$ and no high $\mathrm{SCC}=0$. Logit is the link function of the mean of the response variable, $\alpha$ is the estimate of the baseline odds of occurrence of high SCC or IMI, $\mathrm{DP}_{i}$ indicates the DP length $(i=0$ or $30 \mathrm{~d})$, and $\varepsilon_{j}$ represents the random residual term from a binary distribution.

To evaluate changes in presence of a udder pathogen across the DP and presence of a bacterial udder pathogen (no growth, culture of a major udder pathogen, or culture of another udder pathogen) prepartum (wk 5) and postpartum (wk 1), quarter milk samples were compared using Model 1 with a multinomial distribution and cumlogit link. The incidence of postpartum bacterial culture was assessed within observations of bacterial culture prepartum (no growth, major udder pathogen, or other udder pathogen).

The incidences of quarters infected with different types of bacterial udder pathogens and the SCC in individual quarter milk samples from cows with a 0 - or 30-d DP in wk 5 prepartum and wk 1 and 5 postpartum were evaluated using a mixed linear model (PROC MIXED; Model 2). Fixed effects included in the model were treatment (in wk 5 prepartum and wk 1 postpartum: 0-d or 30-d DP; in wk 5 postpartum: 0-d DP LEL, 0-d DP SEL, or 30-d DP SEL), postpartum parity (2 or $\geq 3$ ), and week after calving (wk 5 prepartum or wk 1 or 5 postpartum) and their 2-way interactions.

$S C C$, Elevations of SCC, and Clinical Mastitis of Cows Receiving Different Diets After Different DP Lengths. Weekly SCC and SCC corrected for milk yield ( $\mathrm{kg}$ of milk/d) were analyzed using a mixed linear model (PROC MIXED) including week as a repeated measurement effect with cow as the repeated subject (Model 3). Fixed effects of treatment (0-d DP LEL, 0-d DP SEL, or 30-d DP SEL), ration (G or L), postpartum parity ( 2 or $\geq 3$ ), week after calving (wk 1 through 44), and their 2-way interactions were included in the model. To obtain SCC corrected for milk yield, average weekly milk yield ( $\mathrm{kg}$ of milk/d) was included in the model for SCC (Steeneveld et al., 2013). To account for the effect of season on variation in SCC (Bodoh et al., 1976; Green et al., 2006; Olde Riekerink et al., 2007), calving season (meteorological winter, spring, summer, or autumn) was included as a random effect. A first-order autoregressive covariance matrix was the best fit according to Akaike corrected information criterion and was used to account for within-cow variation.

For the binary variables "at least 1 elevation of SCC between 3 and 44 wk postpartum" and "at least 1 case of clinical mastitis between 1 and 44 wk postpartum," for each cow a binary distribution and the default logit link function were used to model the mixed linear regression analysis (PROC GLIMMIX; Model 4). Fixed effects of treatment (0-d DP LEL, 0-d DP SEL, or 30-d DP SEL), ration ( $G$ or L), postpartum parity (2 
or $\geq 3$ ), and their 2-way interactions were included in the model. An elevation of SCC was defined as SCC $\geq 200,000$ cells $/ \mathrm{mL}$ after 2 previous weeks with SCC $<200,000$ cells $/ \mathrm{mL}$ (Schukken et al., 2003). Elevations of SCC and numbers of cases of clinical mastitis per cow in the subsequent lactation after different DP lengths were analyzed among treatments (0-d DP LEL, 0-d DP SEL, or 30-d DP SEL) using Model 4, with a Poisson distribution for the dependent variables and the default $\log$ link function in a mixed linear regression analysis (PROC GLIMMIX).

To evaluate survival time to first elevation of SCC or first case of clinical mastitis after different DP lengths, a survival analysis (PROC LIFETEST) was used to obtain Kaplan-Meier curves (Model 5). For cows that did not have an elevation of SCC or a case of clinical mastitis within 44 wk postpartum, the survival time was censored at $44 \mathrm{wk}$ postpartum. To evaluate statistical differences of Kaplan-Meier curves among treatments, a Cox proportional hazards model (PROC PHREG) was used with pairwise comparison.

Associations Between Metabolic Status, Milk Yield, and Udder Health After Different DP Lengths. For associations between metabolic status and udder health postpartum, data on FPCM yield, energy intake, EB, and plasma FFA, BHB, glucose, and IGF-1 concentration in wk 1 to 7 (van Hoeij et al., 2017a) and on FPCM yield, energy intake, EB, and plasma insulin, IGF-1, and GH concentration in wk 1 to 44 (van Hoeij et al., 2017b) from previous studies were used. To evaluate associations between weekly metabolic status and SCC in wk 1 to 7 and wk 1 to 44, a mixed linear model (PROC MIXED; Model 6) was used, including week as a repeated measurement effect and with cow as the repeated subject. A firstorder autoregressive covariance matrix was the best fit according to Akaike corrected information criterion and was used to account for within-cow variation. The independent variables were treatment (0-d DP LEL, 0-d DP SEL, or 30-d DP SEL), ration ( $G$ or L; only for wk 1-44), parity (2 or $\geq 3$ ), and one of the following metabolic or milk production variables: weekly FPCM yield, EB, energy intake, plasma insulin, IGF-1, $\mathrm{GH}, \mathrm{FFA}, \mathrm{BHB}$, or glucose concentration to assess the coefficient estimate $(\beta)$ of the variable. Plasma insulin, IGF-1, and GH were available weekly from wh 1 to 10 and every other week from wk 12 to 44 in lactation. Plasma FFA, BHB, and glucose were available weekly from wk 1 to 7 in lactation. The natural logarithm was used for plasma FFA, BHB, and GH concentration to approximate normality.

To evaluate changes in metabolic status of cows in the $3 \mathrm{wk}$ preceding an elevation of SCC or a case of clinical mastitis, a mixed linear model (Model 7) was used, including week as a repeated measurement effect and with cow as the repeated subject. Cows with an elevation of SCC or case of clinical mastitis in wk 1 to 3 of lactation or without an elevation of SCC or case of clinical mastitis in lactation were not included in the data set for this analysis. In wk 4 to 7,9 cows had at least 1 elevation of SCC and 3 cows had at least 1 case of clinical mastitis. In wk 4 to 44, 53 cows had at least 1 elevation of SCC and 17 cows had at least 1 case of clinical mastitis. A first-order autoregressive covariance matrix was the best fit according to Akaike corrected information criterion and was used to account for within-cow variation. The dependent variable in these statistical analyses was one the following metabolic or milk production variables: weekly FPCM yield, EB, energy intake, plasma insulin, IGF-1, GH, FFA, BHB, or glucose concentration in the last $3 \mathrm{wk}$ before the first elevation of SCC or the first case of clinical mastitis within wk 4 to 44 of lactation. Preliminary analyses showed that dependent variables were not different among weeks before the last $3 \mathrm{wk}$ before the first elevation of SCC or the first case of clinical mastitis. The independent variables included in the model were treatment (0-d DP LEL, 0-d DP SEL, or 30-d DP SEL), ration (G or L; not for the plasma FFA, BHB, or glucose concentration), parity ( 2 or $\geq 3$ ), and week before elevation of SCC or case of clinical mastitis (wk $-3,-2$, or -1 ). To evaluate normality of residuals, a normality test was used in data distribution (PROC UNIVARIATE), and skewness between -1 and 1 , kurtosis between -2 and 2, and a nonsignificant Shapiro-Wilk test were regarded as indicating normality.

\section{RESULTS}

\section{Prepartum and Postpartum Milk Yield}

Prepartum FPCM yield was $13.9 \mathrm{~kg} / \mathrm{d}$ for cows with a 0 -d DP and $0 \mathrm{~kg} / \mathrm{d}$ for cows with a $30-\mathrm{d}$ DP in wk 4 to 1 prepartum (van Hoeij et al., 2017a). The FPCM yield was $27.1 \mathrm{~kg} / \mathrm{d}$ for cows with a 0 -d D LEL, $27.4 \mathrm{~kg} / \mathrm{d}$ for cows with a 0 -d DP SEL, and $32.3 \mathrm{~kg} / \mathrm{d}$ for cows with a 30-d DP SEL in wk 1 to 44 of lactation (van Hoeij et al., 2017b).

\section{Occurrence of IMI Across Different DP Lengths}

Based on weekly milk samples, the occurrence of SCC $\geq 200,000$ cells $/ \mathrm{mL}$ at the last test day before 37 $\mathrm{d}$ before the expected calving date (median $=51 \mathrm{~d}$ prepartum; $P=0.18$ ) and at the first test day after 10 DIM $(P=0.77)$ did not differ between DP lengths (Table 2). Similarly, the proportion of cows with a chronically or cured high SCC $(P=0.92)$ or new or no 
high SCC $(P=0.77)$ in weekly milk samples did not differ between DP lengths.

\section{Bacterial Infections with Different Types of Udder Pathogens in Quarters of Cows with a 0-d or 30-d DP}

Based on bacterial culture of quarter milk samples, the proportion of quarters with no growth $(P=0.49)$, with major udder pathogens $(P=0.09)$, or with other udder pathogens $(P=0.79)$ did not differ between cows with 0 -d or $30-\mathrm{d}$ DP in wk 5 prepartum or wk 1 postpartum or among treatments in wk 5 postpartum (Table 3). An interaction of treatment and parity was present for the proportion of quarters with no growth or infected with a major or other udder pathogen $(P$ $=0.03 ;$ Figure 1a). The effect of parity depended on treatment; cows with a $30-\mathrm{d}$ DP or $30-\mathrm{d}$ DP SEL and parity $\geq 3$ had a lower proportion of quarters with a negative culture than cows with a 30-d DP or 30-d DP SEL and parity $2(P<0.01)$. This effect was not present in cows with a 0 -d DP or 0 -d DP LEL $(P \geq$ $0.05)$ but was present in cows with a 0 -d DP SEL $(P$ $<0.01)$. An interaction of parity with week relative to calving was present for the proportion of quarters with no growth or infected with a major or other udder pathogen $(P<0.01 ;$ Figure $1 \mathrm{~b})$. In general, differences between parities were greatest in wk 5 prepartum and smallest in wk 5 postpartum.

Table 2. Number (\%) of cows with a low SCC $(<200,000$ cells $/ \mathrm{mL})$ or high SCC $(\geq 200,000$ cells $/ \mathrm{mL})$ at the last test day ${ }^{1}$ and at the first test day (median $=13 \mathrm{~d}$ postpartum) after a 0 - or 30 -d dry period

\begin{tabular}{|c|c|c|c|}
\hline \multirow[b]{2}{*}{ Item $^{2}$} & \multicolumn{2}{|c|}{ Dry period length } & \multirow[b]{2}{*}{$P$-value } \\
\hline & $0 \mathrm{~d}$ & $30 \mathrm{~d}$ & \\
\hline Total cows & 77 & 38 & \\
\hline SCC $<200,000$ prepartum & $65(84)$ & $31(82)$ & \\
\hline SCC $>200,000$ prepartum & $12(16)$ & $7(18)$ & 0.70 \\
\hline SCC $<200,000$ postpartum & $57(74)$ & $27(71)$ & \\
\hline SCC $>200,000$ postpartum & $20(26)$ & $11(29)$ & 0.74 \\
\hline \multicolumn{4}{|l|}{ High SCC prepartum } \\
\hline Chronic high SCC & $4(33)$ & $2(29)$ & \\
\hline Cured high SCC & $8(67)$ & $5(71)$ & 0.88 \\
\hline \multicolumn{4}{|l|}{ Low SCC prepartum } \\
\hline New high SCC & $16(25)$ & $9(29)$ & \\
\hline No high SCC & $49(75)$ & $22(71)$ & 0.63 \\
\hline
\end{tabular}

${ }^{1}$ Last test day is the last test day before the drying-off day for cows with a 30 -d dry period (median $=51 \mathrm{~d}$ prepartum).

${ }^{2}$ Chronically high $\mathrm{SCC}=\mathrm{SCC} \geq 200,000$ cells $/ \mathrm{mL}$ before and after calving; cured high $\mathrm{SCC}=\mathrm{SCC} \geq 200,000$ cells $/ \mathrm{mL}$ before calving and SCC $<200,000$ cells $/ \mathrm{mL}$ after calving; newly high SCC $=$ SCC $<200,000$ cells $/ \mathrm{mL}$ before calving and $\mathrm{SCC} \geq 200,000$ cells $/ \mathrm{mL}$ after calving; no high SCC $=$ SCC $<200,000$ cells $/ \mathrm{mL}$ before and after calving. Within observations of prepartum high SCC, the proportion of postpartum chronic high or cured high SCC was analyzed (logistic regression with binary distribution). Within observations of prepartum low SCC, the proportion of postpartum new high SCC or no high SCC was analyzed (logistic regression with binary distribution).

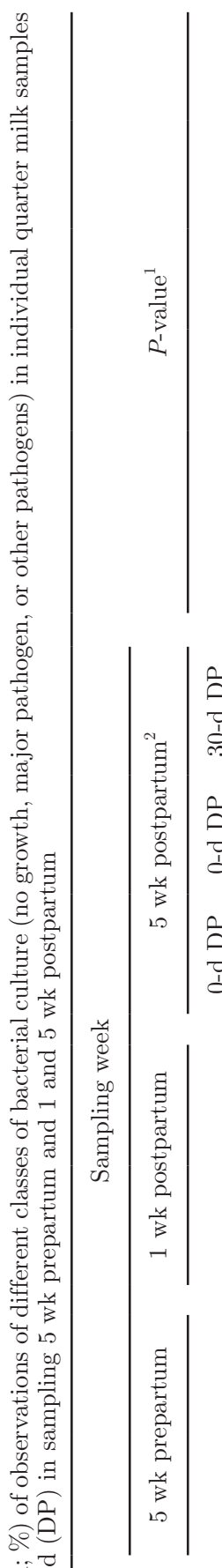

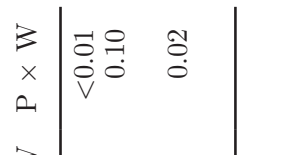

$$
\begin{aligned}
& 3 \text { 구오ํ } \\
& \times \quad \stackrel{0}{0} \\
& \text { H } \\
& \text { ค }
\end{aligned}
$$$$
\text { (1) }
$$

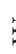$$
\beta \mid \begin{array}{lll}
0 & 0 \\
0 & 0 & 0 \\
0 & 0 & 0
\end{array}
$$

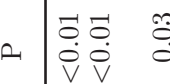$$
\text { F }
$$ 


\section{SCC, Elevations of SCC, and Clinical Mastitis of Cows Receiving Different Diets After Different DP Lengths}

Dry period length and dietary energy level (0-d DP LEL, 0-d DP SEL, or 30-d DP SEL) did not have an effect on SCC $(P=0.39)$ and SCC corrected for milk yield $(P=0.36)$ in wk 1 to 7 of lactation. Cows with parity $\geq 3$ had a greater SCC $(P=0.02)$ and SCC corrected

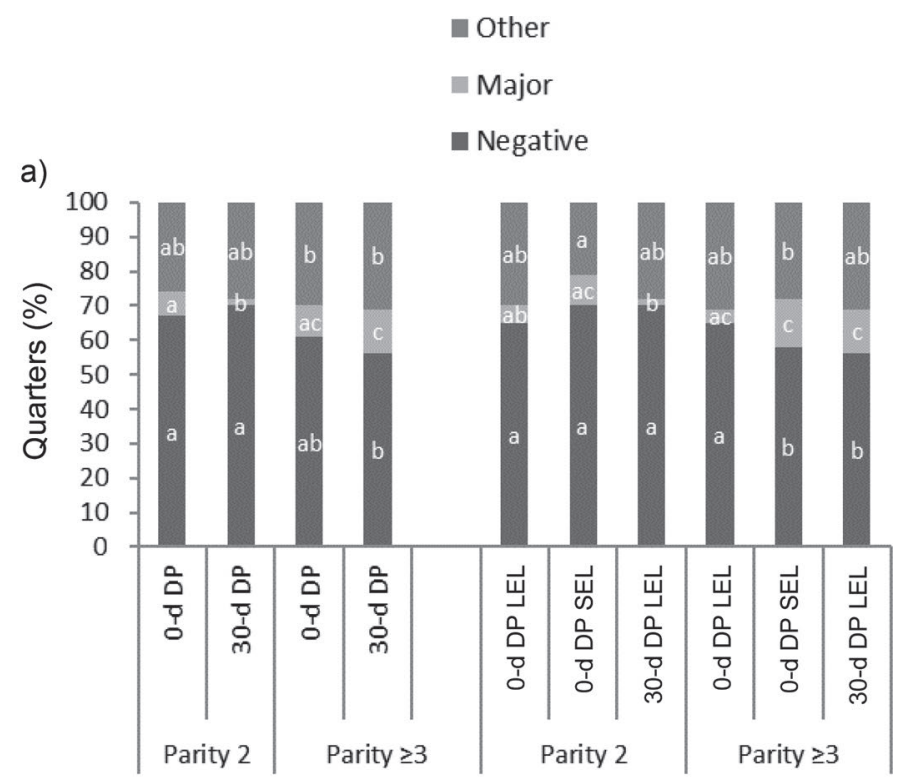

b)

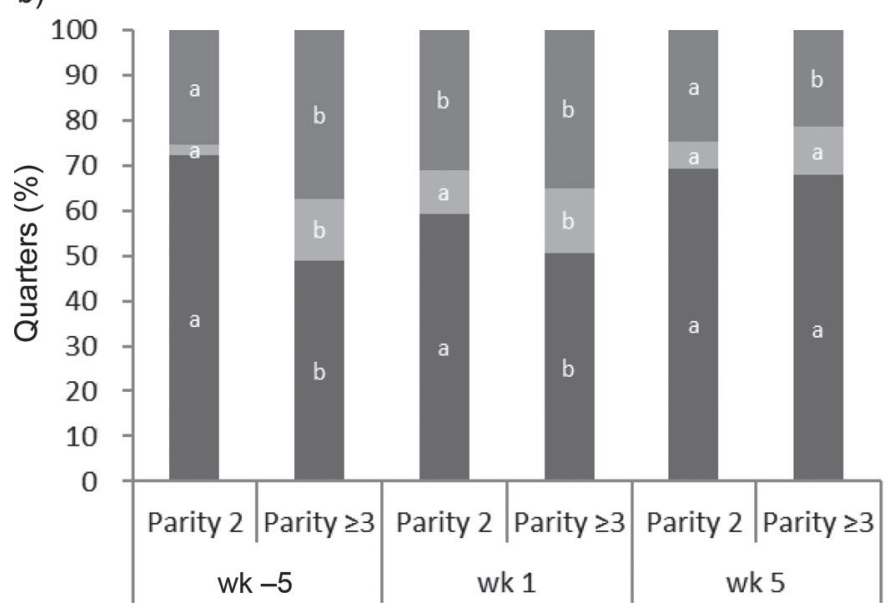

Figure 1. (a) Interaction of parity and treatment for the proportion of quarters with no growth or infected with a major udder pathogen or another udder pathogen. In wk 5 postpartum, cows with a 0-d dry period (DP) received either a low energy level (0-d DP LEL) based on the requirement for their expected milk yield or a standard energy level (0-d DP SEL) based on the expected milk yield of cows with a 30-d DP (30-d DP SEL). (b) Interaction of parity with week relative to calving (wk 5 prepartum or wk 1 or 5 postpartum) for the proportion of quarters with no growth or infected with a major udder pathogen or another udder pathogen. Values within pathogen with different letters $(\mathrm{a}-\mathrm{c})$ differ $(P<0.05)$. for milk yield $(P<0.01)$ in wk 1 to 7 of lactation than cows with parity 2 (Table 4 ). An interaction between treatment and parity was present for SCC in wk 8 to 44 of lactation. Cows with a 0-d DP SEL or 30-d DP SEL and parity $\geq 3$ had a greater SCC than cows with parity $2(P<0.01)$; this effect was not present for cows with a 0 -d DP LEL $(P=0.36$; Figure 2a). An interaction of treatment and ration was present for SCC (Figure $2 \mathrm{~b}$ ) and SCC corrected for milk yield (Figure 2c) in wk 8 to 44 of lactation. Cows with a 0-d DP SEL fed a G ration had a greater $\mathrm{SCC}(P=0.02)$ or SCC corrected for milk yield $(P<0.01)$ than cows fed an L ration, whereas this effect was not present for cows with a 0 -d DP LEL $(P=0.10$ and 0.66 , respectively) or $30-\mathrm{d}$ DP SEL $(P=0.14$ and 0.94 , respectively). An interaction of parity and ration was present for SCC corrected for milk yield in wk 8 to 44 (Figure 2d). Cows with parity $\geq 3$ fed a $\mathrm{G}$ ration had a greater $\mathrm{SCC}$ corrected for milk yield than cows fed an $\mathrm{L}$ ration $(P<0.01)$. This effect was not present for cows with parity $2(P=0.83)$. Treatment did not have an effect on the occurrence of at least 1 elevation of $\operatorname{SCC}(P=0.71)$ or at least 1 case of clinical mastitis $(P=0.15)$, the number of elevations of SCC per affected cow $(P=0.31)$, or the number of mastitis cases per treated cow $(P=0.74)$. Cows with parity $\geq 3$ had a greater occurrence of at least 1 elevation of SCC than cows with parity $2(P=$ $0.02)$. The proportion of cows that had an elevation of SCC in the first $44 \mathrm{wk}$ of lactation was 53,55 , and $47 \%$ for cows with a 0-d DP LEL, 0-d DP SEL, and 30-d DP SEL, respectively. Survival time before elevation of SCC did not differ between treatments $(P=0.89)$. The proportion of cows that had a case of clinical mastitis within 44 wk of lactation was 27,31 , and $17 \%$ for cows with a 0-d DP LEL, 0-d DP SEL, and 30-d DP SEL, respectively. Survival time before the development of clinical mastitis was not different between treatments $(P=0.26)$. However, cows with a 0 -d DP SEL tended to have a greater hazard of developing clinical mastitis at any time in lactation (hazard ratio $=2.17 ; 95 \%$ $\mathrm{CI}=0.85-5.05)$ compared with cows with a $30-\mathrm{d}$ DP SEL $(P<0.10$; Figure 3$)$. Cows with a 0 -d DP LEL did not have a greater hazard for developing a case of clinical mastitis than cows with a 0-d DP SEL (hazard ratio $=0.84 ; 95 \% \mathrm{CI}=0.37-1.89 ; P=0.67)$ or cows with a $30-\mathrm{d}$ DP SEL (hazard ratio $=1.81 ; 95 \%$ CI $=$ $0.70-4.67 ; P=0.22)$.

\section{Associations Between Metabolic Status, Milk Yield, and Udder Health After Different DP Lengths}

Mean plasma GH concentrations in wk 1 to 7 were 4.23 (3.82-4.68), 4.47 (4.03-4.95), and 5.35 (4.86-5.89) $\mu \mathrm{g} / \mathrm{L}$ for cows with a $0-\mathrm{d}$ DP LEL, 0-d DP SEL, or 30-d 
VAN HOEIJ ET AL.

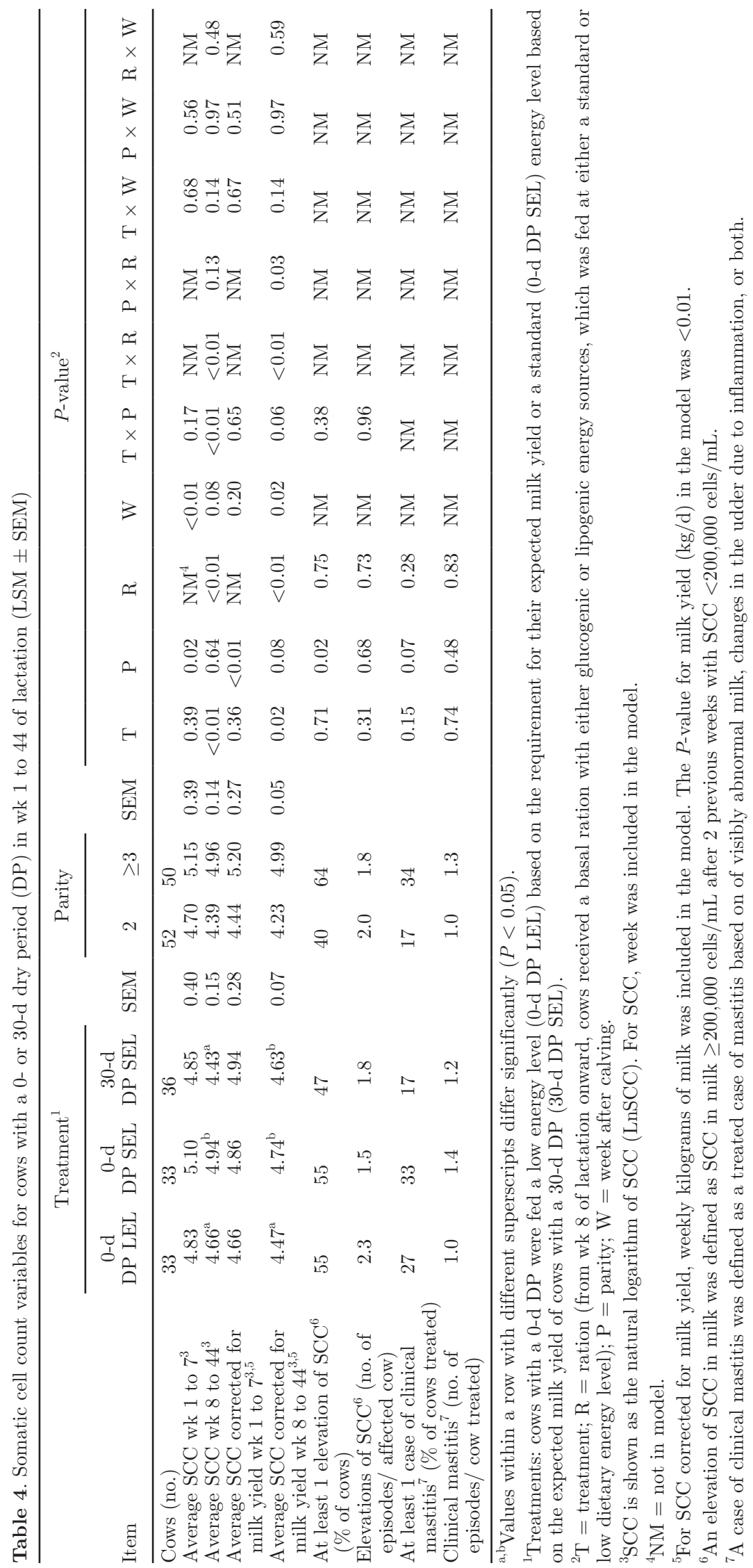


a)

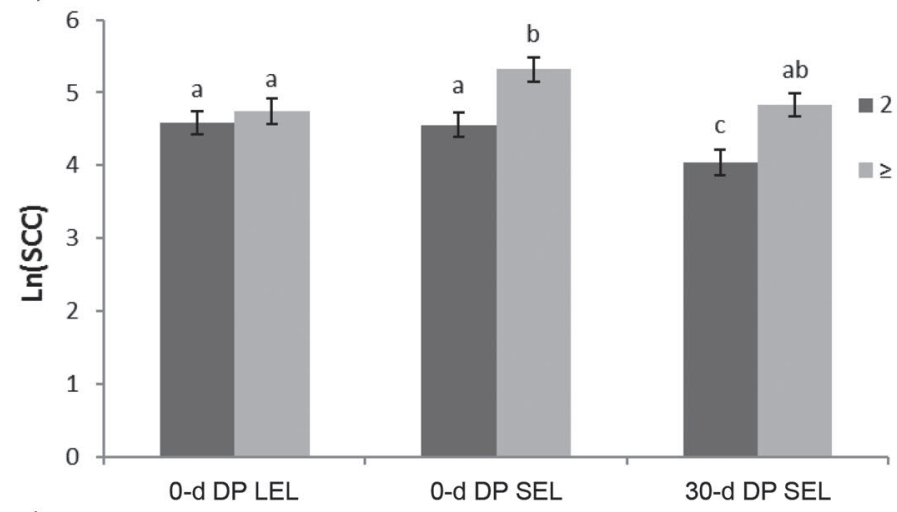

c)

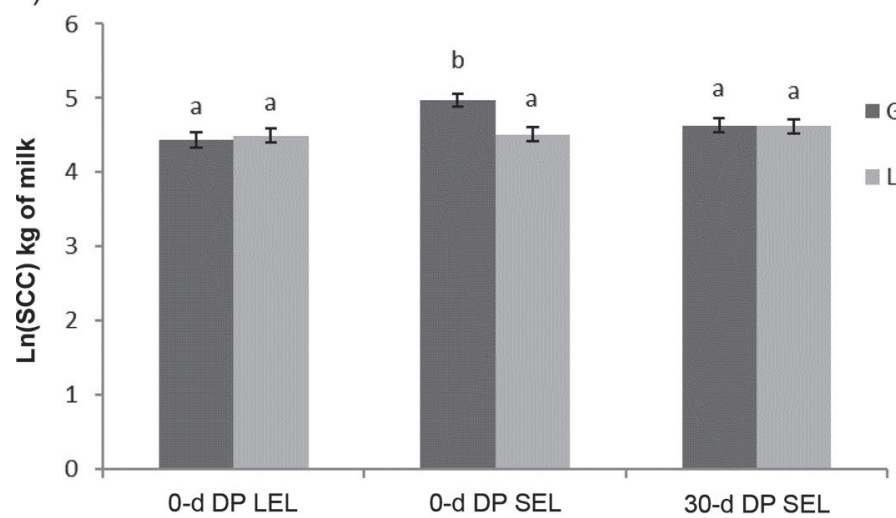

b)

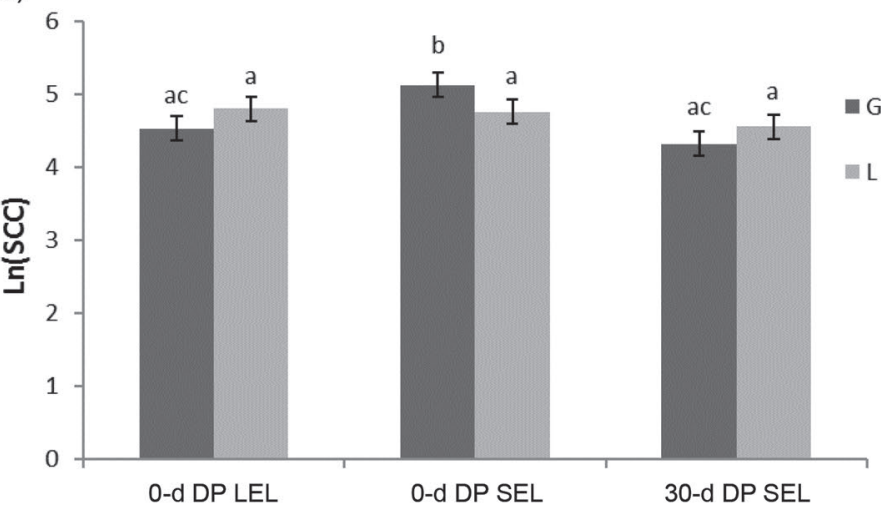

d)

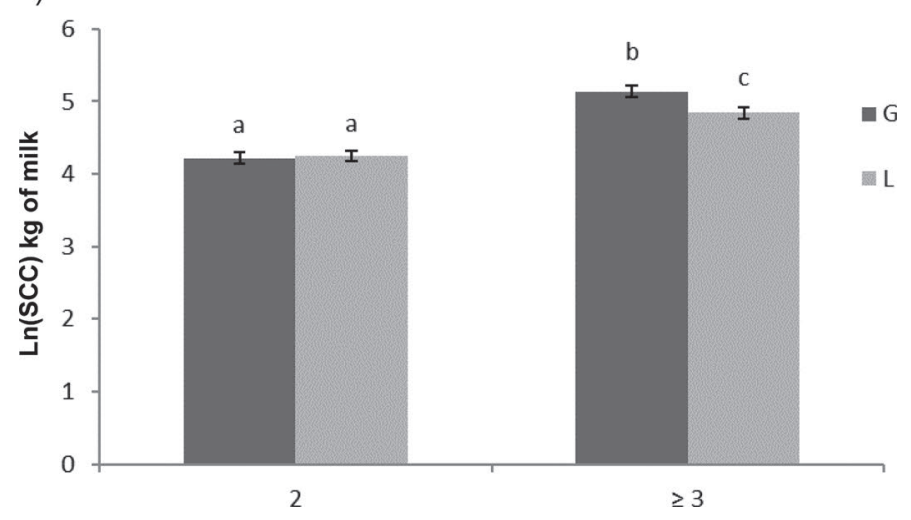

Figure 2. Somatic cell count (presented as the natural logarithm of SCC; LSM \pm SEM) in wk 8 to 44 postpartum for (a) the interaction between treatment and parity $(2$ or $\geq 3)$ and (b) the interaction between treatment and postpartum ration $(\mathrm{G}=$ glucogenic; $\mathrm{L}=$ lipogenic). Somatic cell count corrected for milk yield for (c) the interaction between treatment and ration and (d) the interaction between parity and ration. Treatments: cows with a 0-d dry period (DP) received either a low energy level (0-d DP LEL) based on the requirement for their expected milk yield or a standard energy level (0-d DP SEL) based on the expected milk yield of cows with a 30-d DP (30-d DP SEL). Values with different letters $(\mathrm{a}-\mathrm{c})$ among treatments or parities differ $(P<0.05)$.

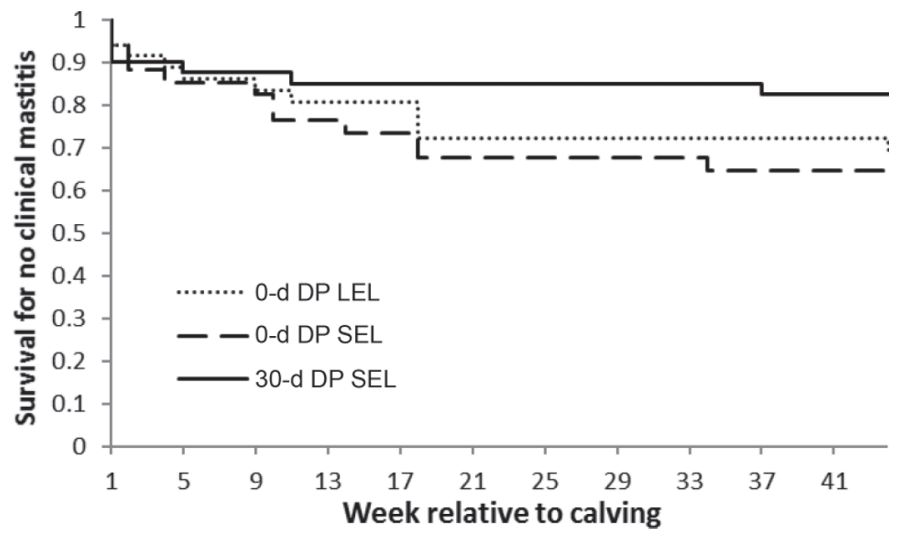

Figure 3. Kaplan-Meier survival curve. The survival function is the time of survival for no case of clinical mastitis in wk 1 to 44 in lactation following a 0-d dry period (DP) and a low energy level based on the requirement for expected milk yield (0-d DP LEL), a 0-d DP and standard energy level (0-d DP SEL), or a 30-d DP and a standard energy level based on the requirement for their expected milk yield (30-d DP SEL).
DP SEL, respectively, and were lower for cows with a 0 -d DP than for cows with a $30-d$ DP $(P<0.01)$, but were not affected by dietary energy level. In wk 1 to 7 of lactation, FPCM yield $(P<0.01)$ and energy intake $(P<0.05)$ were negatively associated with SCC, and $\mathrm{EB}$ and plasma insulin concentration were positively associated with SCC $(P<0.01$; Table 5$)$. In wk 1 to 44 of lactation, FPCM yield and energy intake were negatively associated with SCC $(P<0.01)$, and EB $(P$ $<0.05)$ and plasma insulin concentration $(P<0.01)$ were positively associated with SCC.

Cows that had at least 1 elevation of SCC in wk 4 to 44 of lactation had a greater EB in wk 2 than in wk 3 before SCC elevation $(P=0.01)$, had a greater energy intake in wk 2 than in wk 3 or wk 1 before SCC elevation $(P<0.01)$, had a lower plasma FFA concentration $(P=0.05)$, and tended to have a greater plasma IGF-1 concentration in the week of an elevation of SCC than in the week before the elevation $(P<0.10$; Table 6$)$. In cows that had at least 1 case of clinical mastitis in wk 
Table 5. Associations between $\mathrm{SCC}^{1}$ and fat- and protein-corrected milk (FPCM) yield; energy balance; energy intake; and plasma insulin, IGF-1, growth hormone, free fatty acid (FFA), BHB, and glucose concentrations in wk 1 to 44 of lactation

\begin{tabular}{|c|c|}
\hline Item & Regression coefficient (SEM) \\
\hline \multicolumn{2}{|l|}{ wk 1-7 of lactation } \\
\hline $\mathrm{FPCM}(\mathrm{kg} / \mathrm{d})$ & $-0.058(0.008)^{* * *}$ \\
\hline Energy balance $^{2}\left(\mathrm{~kJ} / \mathrm{kg}^{0.75}\right.$ per day $)$ & $1.58 \times 10^{-3}\left(0.34 \times 10^{-3}\right)^{* * *}$ \\
\hline Energy intake $\left(\mathrm{kJ} / \mathrm{kg}^{0.75}\right.$ per day) & $-0.99 \times 10^{-3}\left(0.47 \times 10^{-3}\right)^{*}$ \\
\hline Insulin $(\mu \mathrm{U} / \mathrm{mL})$ & $0.02(0.004)^{* * *}$ \\
\hline IGF-1 (ng/mL) & $1.03 \times 10^{-3}\left(0.92 \times 10^{-3}\right)$ \\
\hline Growth hormone $^{3}(\mu \mathrm{g} / \mathrm{L})$ & $-0.09(0.07)$ \\
\hline $\mathrm{FFA}^{3,4}(\mathrm{mmol} / \mathrm{L})$ & $-0.02(0.05)$ \\
\hline $\mathrm{BHB}^{3,4}(\mathrm{mmol} / \mathrm{L})$ & $-0.09(0.09)$ \\
\hline Glucose $^{4}(\mathrm{mmol} / \mathrm{L})$ & $0.04(0.07)$ \\
\hline \multicolumn{2}{|l|}{ wk $1-44$ of lactation } \\
\hline $\mathrm{FPCM}(\mathrm{kg} / \mathrm{d})$ & $-0.045(0.004)^{* * *}$ \\
\hline Energy balance $^{2}\left(\mathrm{~kJ} / \mathrm{kg}^{0.75}\right.$ per day $)$ & $0.31 \times 10^{-3}\left(0.15 \times 10^{-3}\right)^{*}$ \\
\hline Energy intake $\left(\mathrm{kJ} / \mathrm{kg}^{0.75}\right.$ per day) & $-0.95 \times 10^{-3}\left(0.16 \times 10^{-3}\right) * * *$ \\
\hline Insulin $(\mu \mathrm{U} / \mathrm{mL})$ & $0.005(0.001)^{* * *}$ \\
\hline IGF-1 (ng/mL) & $0.62 \times 10^{-3}\left(0.38 \times 10^{-3}\right)$ \\
\hline Growth hormone $^{3}(\mu \mathrm{g} / \mathrm{L})$ & $-0.09(0.03)$ \\
\hline
\end{tabular}

${ }^{1}$ SCC is shown as the natural logarithm of SCC (LnSCC).

${ }^{2}$ Energy balance calculated according to Van Es (1975).

${ }^{3}$ Analyzed as the natural logarithm of the FFA, BHB, or growth hormone concentration.

${ }^{4}$ Plasma FFA, BHB, and glucose concentrations were not measured after wk 7 in lactation.

${ }^{*} P<0.05$. ${ }^{* * *} P<0.001$. $P$-values denote regression coefficients being significantly different from 0 .

4 to 44 of lactation, FPCM yield was lower and energy intake was greater in wk 1 than in wk 2 and 3 before a case of clinical mastitis, and plasma GH concentration was greater in wk 2 than in wk 1 and 3 before a case of clinical mastitis $(P<0.01$; Table 7$)$. In the week with the first case of clinical mastitis, $\operatorname{EB}(P=0.02)$ and plasma insulin concentration $(P=0.03)$ were greater and FPCM yield and plasma GH concentration tended to be lower than in the week before the first case of clinical mastitis $(P<0.10)$.

Table 6. Fat- and protein-corrected milk (FPCM) yield; energy balance; energy intake; and plasma insulin, IGF-1, growth hormone, free fatty acid (FFA), BHB, and glucose concentrations in the last $3 \mathrm{wk}$ before the first elevation of SCC within wk 4 to 44 of lactation ${ }^{1}$

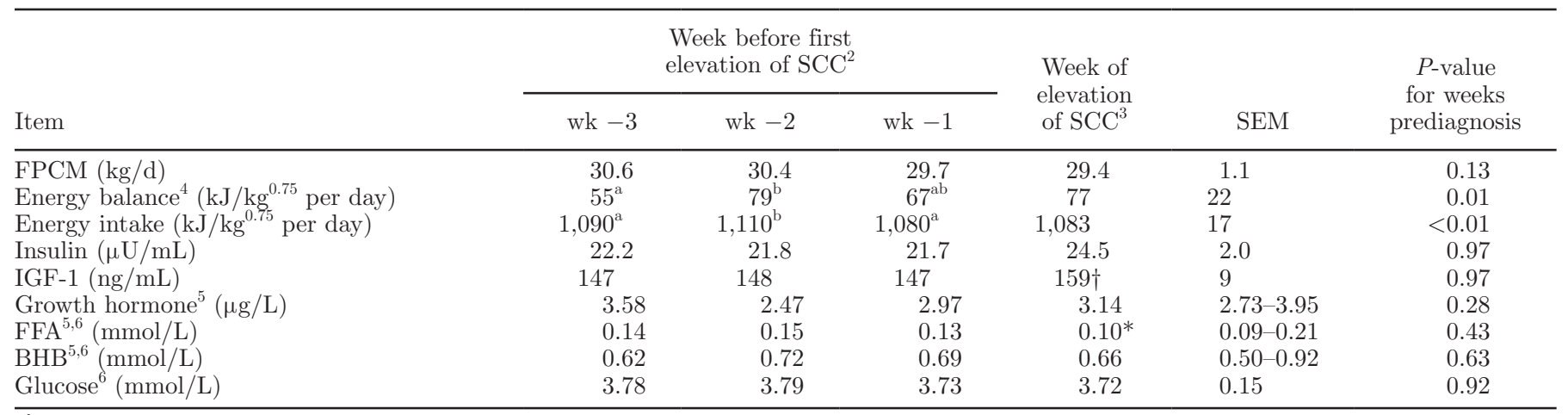

${ }^{\mathrm{a}, \mathrm{b}}$ Values among weeks prediagnosis with different superscripts differ significantly $(P<0.05)$.

${ }^{1}$ Values represent LSM \pm SEM. Mean weeks in lactation was 18 for first elevation of SCC. Between wk 4 and 44,53 elevations of SCC occurred.

${ }^{2}$ An elevation of SCC in milk was defined as SCC in milk $\geq 200,000$ cells $/ \mathrm{mL}$ after 2 previous weeks with $\mathrm{SCC}<200,000$ cells $/ \mathrm{mL}$.

${ }^{3}$ Value for week of elevation of SCC was not included for statistical analyses.

${ }^{4}$ Energy balance calculated according to Van Es (1975).

${ }^{5}$ Analyzed as the natural logarithm of the FFA, BHB, or growth hormone concentrations and presented with confidence interval instead of SEM.

${ }^{6}$ Plasma FFA, BHB, and glucose concentrations were not measured after wk 7 in lactation. Between wk 4 and 7 of lactation, 9 cows had a first elevation of SCC.

$\dagger P<0.10$. ${ }^{*} P<0.05$. Value in week of elevation of SCC is different from week prediagnosis $($ wk -1$)$. 
Table 7. Fat- and protein-corrected milk (FPCM) yield; energy balance; energy intake; and plasma insulin, IGF-1, growth hormone, free fatty acid (FFA), BHB, and glucose concentrations in the first case of clinical mastitis within wk 4 to 44 of lactation $^{1}$

\begin{tabular}{|c|c|c|c|c|c|c|}
\hline \multirow[b]{2}{*}{ Item } & \multicolumn{3}{|c|}{$\begin{array}{l}\text { Week before first case } \\
\text { of clinical mastitis }\end{array}$} & \multirow{2}{*}{$\begin{array}{c}\text { Week } \\
\text { of clinical } \\
\text { mastitis }^{2}\end{array}$} & \multirow[b]{2}{*}{ SEM } & \multirow{2}{*}{$\begin{array}{c}P \text {-value } \\
\text { for weeks } \\
\text { prediagnosi }\end{array}$} \\
\hline & wk -3 & wk -2 & wk -1 & & & \\
\hline$\overline{\mathrm{FPCM}(\mathrm{kg} / \mathrm{d})}$ & $34.3^{\mathrm{a}}$ & $34.1^{\mathrm{a}}$ & $33.8^{\mathrm{b}}$ & $33.0 \dagger$ & 1.9 & $<0.01$ \\
\hline Energy balance $^{3}\left(\mathrm{~kJ} / \mathrm{kg}^{0.75}\right.$ per day $)$ & -27 & -18 & 5 & $42^{*}$ & 41 & 0.15 \\
\hline Energy intake $\left(\mathrm{kJ} / \mathrm{kg}^{0.75}\right.$ per day) & $1,109^{\mathrm{a}}$ & $1,112^{\mathrm{a}}$ & $1,129^{\mathrm{b}}$ & 1,141 & 33 & $<0.01$ \\
\hline Insulin $(\mu \mathrm{U} / \mathrm{mL})$ & 15.7 & 16.1 & 14.0 & $17.9^{*}$ & 2.1 & 0.27 \\
\hline $\mathrm{FFA}^{4,5}(\mathrm{mmol} / \mathrm{L})$ & 0.13 & 0.13 & 0.13 & 0.10 & $0.05-0.27$ & 0.26 \\
\hline $\mathrm{BHB}^{4,5}(\mathrm{mmol} / \mathrm{L})$ & 0.70 & 0.55 & 0.59 & 0.63 & $0.45-0.86$ & 0.75 \\
\hline Glucose $^{5}(\mathrm{mmol} / \mathrm{L})$ & 3.80 & 3.80 & 3.74 & 3.83 & 0.10 & 0.79 \\
\hline
\end{tabular}

\footnotetext{
a,b Values among weeks prediagnosis with different superscripts differ significantly $(P<0.05)$.

${ }^{1}$ Values represent LSM \pm SEM. Mean weeks in lactation was 14 for first case of clinical mastitis. Between wk 4 and 44 , 17 cases of clinical mastitis occurred.

${ }^{2}$ Value for week of clinical mastitis was not included for statistical analyses.

${ }^{3}$ Energy balance calculated according to Van Es (1975).

${ }^{4}$ Analyzed as the natural logarithm of the FFA, BHB, or growth hormone concentrations and presented with confidence interval instead of SEM. ${ }^{5}$ Plasma FFA, BHB, and glucose concentrations were not measured after wk 7 in lactation. Between wk 4 and 7 of lactation, 3 cows had a first case of clinical mastitis.

$\dagger P<0.10$. ${ }^{*} P<0.05$. Value in week of clinical mastitis is different from week prediagnosis $(\mathrm{wk}-1)$.
}

\section{DISCUSSION}

\section{Effects of DP Length Without Dry Cow Antibiotics on Udder Health}

In the current study no dry cow antibiotics were used in cows with a 30-d DP, in contrast to previous studies that evaluated the effect of DP length on udder health (Rastani et al., 2005; Watters et al., 2008; Santschi et al., 2011). Nevertheless, also in the current study, SCC was increased in cows with a 0-d DP compared with cows with a 30-d DP, which is in line with earlier studies on the effects of DP length with use of dry cow antibiotics (Kuhn et al., 2006; Pezeshki et al., 2007; van Hoeij et al., 2016). Earlier, we hypothesized that the greater SCC after a short or no DP compared with a conventional DP could be associated with (1) lower milk production, (2) prepartum ration, (3) increase in IMI across the DP or precalving period, and (4) increase in IMI during the course of lactation (van Hoeij et al., 2016).

First, the greater SCC in wk 8 to 44 of lactation of cows with a 0-d DP fed a standard energy level compared with a 30-d DP could be associated with the reduction in milk yield (Rastani et al., 2005; Klusmeyer et al., 2009; van Knegsel et al., 2014) due to lower milk-producing capacity of udder cells (Steeneveld et al., 2013) of cows with a 0-d DP compared with cows with a 30-d DP. In line with earlier work (Steeneveld et al., 2013) also in the current study, SCC corrected for milk yield was not different between cows with a $0-d$
DP SEL or a 30-d DP SEL and was even lower for cows with a 0-d DP LEL, which implies that the greater SCC is possibly associated with the lower milk yield in cows with a 0-d DP.

Second, fattening of cows during the DP increases the risk for postpartum ketosis, which is associated with a risk for postpartum clinical mastitis (Leslie et al., 2000). In the current study, cows with a $0-\mathrm{d}$ or 30-d DP had a similar EB, metabolic status, and BCS prepartum (van Hoeij et al., 2017). Therefore, it is unlikely that differences in prepartum fattening affected udder health in the subsequent lactation in the current study.

Third, the greater SCC in wk 8 to 44 of cows with a 0 -d DP fed the standard energy level compared with cows with a $30-\mathrm{d}$ DP is unlikely to be associated with bacterial infections across the DP as the incidence of IMI across the DP and SCC in wk 1 to 7 were not different between DP lengths. This is in contrast to Scherpenzeel et al. (2014), who reported that withholding dry cow antibiotics increased SCC and the occurrence of clinical mastitis in early lactation compared with quarters treated with dry cow antibiotics. Differences between these studies might be explained by the fact that in the current study cows with a short DP not treated with dry cow antibiotics were compared with cows with no DP at all, whereas Scherpenzeel et al. (2014) compared the use of dry cow antibiotics versus no dry cow antibiotics in cows with a conventional DP.

Last, the greater SCC in wk 8 to 44 of cows with a 0 - $d$ DP could be hypothesized to be associated with the greater occurrence of clinical mastitis during wk 1 to 44 
between cows with a 0-d DP fed a standard energy level $(33 \%)$ and cows with a $30-d$ DP (17\%). In previous studies, occurrence of clinical mastitis was not different between cows with a 0-d or 30-d DP with dry cow antibiotics (Rastani et al., 2005; Schlamberger et al., 2010; van Hoeij et al., 2016). Earlier, it was suggested that a lower cell renewal rate and greater proportion of senescent but viable cells in cows with a 0-d DP (Capuco et al., 1997; Annen et al., 2007) may decrease the integrity and defense mechanisms of udder tissue in late lactation compared with cows with a 30-d DP (Collier et al., 2012). In our study, we expected a detrimental effect of withholding dry cow antibiotics in cows with a $30-d$ DP, yet we found a positive effect of a 30-d DP on SCC and risk for clinical mastitis compared with cows with a 0-d DP fed the same energy level. This implies that a 30-d DP is beneficial for udder health compared with a 0-d DP, also in a situation without use of dry cow antibiotics.

\section{Effects of Dietary Energy Level on Udder Health}

Feeding a standard dietary energy level to cows with a 0-d DP increased SCC and SCC corrected for milk yield (the latter when compared with 0-d DP LEL only). Earlier, feeding a greater dietary energy level increased plasma IGF-1, which stimulates cell proliferation in the udder (Flint and Knight, 1997; Reist et al., 2003). It could be hypothesized that, in the current study, feeding a greater dietary energy level (standard level) to cows with a 0-d DP increased udder cell proliferation. Udder cell proliferation was likely further increased in cows with a 0-d DP fed a standard dietary energy level by feeding the more $\mathrm{G}$ nutrients compared with $\mathrm{L}$ nutrients, which increased plasma IGF-1 concentration (Grummer and Rastani, 2004; van Hoeij et al., 2017b).

Cows with a 0-d DP SEL had a greater SCC in wk 8 to 44 as well as a tendency for a greater hazard for clinical mastitis than cows with a $30-d$ DP SEL. Cows with a 0-d DP LEL did not have a greater hazard for clinical mastitis than cows with a $0-\mathrm{d}$ DP SEL or 30-d DP SEL. These results seem to indicate that feeding a standard energy level, instead of reducing the dietary energy level, to cows with a $0-\mathrm{d}$ DP increases the hazard for clinical mastitis and are contrary to our hypothesis that better metabolic status improves udder health. Occurrence of clinical mastitis or the number of cases of clinical mastitis per affected cow were, however, not different between cows with a 0-d DP LEL or 0-d DP SEL, which could be related to an insufficient number of cows per group to achieve statistical power. In a previous epidemiological study, feeding concentrate with the basal ration decreased the incidence rate of clinical mastitis, which was hypothesized to be related to better metabolic status (Barnouin et al., 2005). In contrast, in a case-control study, feeding concentrate increased the incidence rate of clinical mastitis (Waage et al., 1998). Effects of dietary energy level on udder health need to be further elucidated.

\section{Association Between Metabolic Status and Udder Health}

Previous studies suggested that a negative EB is negatively associated with udder health (Leslie et al., 2000; Ingvartsen and Moyes, 2013). In the current study, SCC was negatively associated with FPCM yield and energy intake and positively associated with EB and plasma insulin concentration in dairy cows during the complete lactation period. In previous studies, cows with a better EB had a greater plasma natural antibody concentration (van Knegsel et al., 2007), a lower plasma FFA concentration, and a greater neutrophil activity (Suriyasathaporn et al., 2000) that lowers the risk for an IMI and elevation of SCC (Ingvartsen and Moyes, 2013). The positive association between FFA and SCC was present in wk 1 to 4 of lactation but not from wk 5 of lactation onward (data not presented), which could be associated with the fact that the EB in cows with a $0-d$ DP was not negative from wk 5 onward (van Hoeij et al., 2017a). The positive association between FFA and SCC is likely stronger in cows with a greater negative $\mathrm{EB}$.

An elevation of SCC in wk 4 to 44 was associated with a greater EB and energy intake in wk 2 before an elevation and was associated with a numerical decrease of FPCM in the weeks before an elevation. It could be hypothesized that, in this study, calculated $\mathrm{EB}$ was greater due to greater energy intake in wk 2 before an elevation of SCC and a numerical decrease in FPCM yield but that true EB was lower due to increased immune response associated with subclinical disease before an elevation of SCC, which is reflected in an increased plasma FFA concentration. Plasma IGF-1 concentration tended to be greater in the week of an elevation of SCC than in the last week before an elevation of SCC. A greater plasma IGF-1 concentration implies that during an elevation of SCC more energy was partitioned to the body rather than the udder. In cows with a case of clinical mastitis in wk 4 to 44 , FPCM yield was lower and energy intake was greater in wk 1 than in wk 2 and 3 before a case of clinical mastitis, and plasma GH concentration was lower in wk 1 than in wk 2 before a case of clinical mastitis. In a previous study, clinical mastitis was associated with lower DMI in the same week, although large variability in response 
of DMI to clinical mastitis was observed among cows (González et al., 2008). As a result of greater energy intake and lower FPCM yield, an increase in EB was expected but was not observed. However, the decreasing plasma GH concentration indicates that more energy was being partitioned toward the body and less toward milk production. In the week of clinical mastitis, FPCM yield and plasma GH concentration tended to be lower and $\mathrm{EB}$ and plasma insulin concentration were greater compared with the last week before clinical mastitis, but energy intake did not differ, which is in contrast with results of González et al. (2008). A greater plasma GH concentration was previously observed in cows with induced mastitis and was associated with an increase in leucocytes that may be a result of the effect of GH on bone marrow to release stored immune cells (Burvenich et al., 1999). From this study it appears that associations between metabolic status and clinical mastitis are more pronounced in the week of clinical mastitis than in the weeks before clinical mastitis.

\section{CONCLUSIONS}

Dry period length in cows not treated with dry cow antibiotics did not affect incidence of IMI across the DP or SCC or SCC corrected for milk yield in wk 1 to 7 of lactation. Also during wk 8 to 44 of lactation, occurrence of elevations of SCC or clinical mastitis was not different among treatments. However, cows with a 0-d DP fed a standard energy level, but not cows with a 0-d DP fed a low energy level, had a greater SCC and tended to have a greater hazard for a case of clinical mastitis than cows with a 30-d DP during the complete lactation. This implies that although effects were small, shortening the DP to $30 \mathrm{~d}$ without use of dry cow antibiotics seems more beneficial for udder health in the subsequent lactation compared with complete omission of the DP. Reducing the dietary energy level for cows with a 0-d DP reduced SCC and SCC corrected for milk yield but did not affect occurrence of elevations of SCC or occurrence of cases of clinical mastitis in the subsequent lactation. This implies that dietary energy level can be reduced according to energy requirements for expected milk yield without detrimental effects on udder health in the subsequent lactation for cows with a 0-d DP. In addition, changes in metabolic status were associated with changes in udder health. Lower FPCM yield, lower energy intake, better $\mathrm{EB}$, and greater plasma insulin concentration were associated with a greater SCC. Energy balance increased and energy intake decreased in weeks before elevation in SCC. Moreover, FPCM yield and plasma GH concentration decreased and energy intake increased already in $2 \mathrm{wk}$ before mastitis diagnosis.

\section{ACKNOWLEDGMENTS}

The authors thank DairyNL (Zuivel NL; organization of the Dutch dairy supply chain, The Hague, the Netherlands) and the Dutch Ministry of Economic Affairs (The Hague, the Netherlands) for financing this study. This study is part of the public-private partnership "Sustainable Dairy Chain" (Duurzame Zuivelketen, The Hague, the Netherlands). The authors also thank the staff of the Dairy Campus (Lelystad, the Netherlands), Rudi Koopmanschap (Adaptation Physiology Group, Wageningen University \& Research, Wageningen, the Netherlands), and the Veterinary Physiology Group of the University of Bern (Switzerland) for their technical support and laboratory analyses during the experiment.

\section{REFERENCES}

Annen, E. L., R. J. Collier, M. A. McGuire, J. L. Vicini, J. M. Ballam, and M. J. Lormore. 2004. Effect of modified dry period lengths and bovine somatotropin on yield and composition of milk from dairy cows. J. Dairy Sci. 87:3746-3761. https://doi.org/10.3168/ jds.S0022-0302(04)73513-4.

Annen, E. L., A. C. Fitzgerald, P. C. Gentry, M. A. McGuire, A. V. Capuco, L. H. Baumgard, and R. J. Collier. 2007. Effect of continuous milking and bovine somatotropin supplementation on mammary epithelial cell turnover. J. Dairy Sci. 90:165-183. https://doi .org/10.3168/jds.S0022-0302(07)72618-8.

Barnouin, J., S. Bord, S. Bazin, and M. Chassagne. 2005. Dairy management practices associated with incidence rate of clinical mastitis in low somatic cell score herds in France. J. Dairy Sci. 88:37003709. https://doi.org/10.3168/jds.S0022-0302(05)73056-3.

Barreiro, J. R., C. R. Ferreira, G. B. Sanvido, M. Kostrzewa, T. Maier B. Wegemann, V. Bottcher, M. N. Eberlin, and M. V. dos Santos. 2010. Short communication: Identification of subclinical cow mastitis pathogens in milk by matrix-assisted laser desorption/ionization time-of-flight mass spectrometry. J. Dairy Sci. 93:5661-5667. https://doi.org/10.3168/jds.2010-3614.

Bernier-Dodier, P., L. Delbecchi, G. F. Wagner, B. G. Talbot, and P. Lacasse. 2010. Effect of milking frequency on lactation persistency and mammary gland remodeling in mid-lactation cows. J. Dairy Sci. 93:555-564. https://doi.org/10.3168/jds.2009-2320.

Bodoh, G. W., W. J. Battista, L. H. Schultz, and R. P. Johnston. 1976. Variation in somatic cell counts in dairy herd improvement milk samples. J. Dairy Sci. 59:1119-1123. https://doi.org/10.3168/jds .S0022-0302(76)84331-7.

Burvenich, C., M. J. Paape, D. Hoeben, H. Dosogne, A. M. MassartLeën, and J. Blum. 1999. Modulation of the inflammatory reaction and neutrophil defense of the bovine lactating mammary gland by growth hormone. Domest. Anim. Endocrinol. 17:149-159. https:// doi.org/10.1016/S0739-7240(99)00032-6.

Capuco, A. V., R. M. Akers, and J. J. Smith. 1997. Mammary growth in Holstein cows during the dry period: Quantification of nucleic acids and histology. J. Dairy Sci. 80:477-487. https://doi.org/10 .3168/jds.S0022-0302(97)75960-5.

Church, G. T., L. K. Fox, C. T. Gaskins, D. D. Hancock, and J. M. Gay. 2008. The effect of a shortened dry period on intramammary infections during the subsequent lactation. J. Dairy Sci. 91:4219 4225. https://doi.org/10.3168/jds.2008-1377.

Collier, R. J., E. L. Annen-Dawson, and A. Pezeshki. 2012. Effects of continuous lactation and short dry periods on mammary function and animal health. Animal 6:403-414. https://doi.org/10.1017/ S1751731111002461.

CVB (Centraal Veevoeder Bureau). 2011. Chemische samenstellingen en nutritionele waarden van voedermiddelen (in Dutch). CBV, The Hague, the Netherlands. 
Drackley, J. K. 1999. Biology of dairy cows during the transition period: The final frontier? J. Dairy Sci. 82:2259-2273. https://doi .org/10.3168/jds.S0022-0302(99)75474-3.

Dutch Ministry of Economic Affairs. 2017. Regulation on veterinary drugs (in Dutch). Accessed Sep. 18, 2017. http://wetten.overheid .nl/BWBR0032626/2017-02-15\#Opschrift.

Flint, D. J., and C. H. Knight. 1997. Interactions of prolactin and growth hormone $(\mathrm{GH})$ in the regulation of mammary gland function and epithelial cell survival. J. Mammary. Gland. Biol. Neoplasia 2:41-48. https://doi.org/10.1023/a:1026321529451.

González, L. A., B. J. Tolkamp, M. P. Coffey, A. Ferret, and I. Kyriazakis. 2008. Changes in feeding behavior as possible indicators for the automatic monitoring of health disorders in dairy cows. J. Dairy Sci. 91:1017-1028. https://doi.org/10.3168/jds.2007-0530.

Green, M. J., A. J. Bradley, G. F. Medley, and W. J. Browne. 2007 Cow, farm, and management factors during the dry period that determine the rate of clinical mastitis after calving. J. Dairy Sci. 90:3764-3776. https://doi.org/10.3168/jds.2007-0107.

Green, M. J., A. J. Bradley, H. Newton, and W. J. Browne. 2006. Seasonal variation of bulk milk somatic cell counts in UK dairy herds: Investigations of the summer rise. Prev. Vet. Med. 74:293-308. https://doi.org/ 1016/j.prevetmed.2005.12.005.

Green, M. J., L. E. Green, A. J. Bradley, P. R. Burton, Y. H. Schukken, and G. F. Medley. 2005. Prevalance and associations between bacterial isolates from dry mammary glands of dairy cows. Vet. Rec. 156:71-77.

Grummer, R. R., and R. R. Rastani. 2004. Why reevaluate dry period length? J. Dairy Sci. 87:E77-E85. https://doi.org/10.3168/jds .S0022-0302(04)70063-6.

Gulay, M. S., M. J. Hayen, K. C. Bachman, T. Belloso, M. Liboni, and H. H. Head. 2003. Milk production and feed intake of Holstein cows given short (30-d) or normal (60-d) dry periods. J. Dairy Sci. 86:2030-2038. https://doi.org/10.3168/jds.S0022-0302(03)73792 $-8$.

Ingvartsen, K. L., and K. Moyes. 2013. Nutrition, immune function and health of dairy cattle. Animal 7:112-122. https://doi.org/10 $.1017 /$ S175173111200170X.

ISO. 2013. ISO 9622. Milk and liquid milk products. Guidelines for the application of mid-infrared spectrometry. 2:14. International Organization of Standardization, Geneva, Switzerland.

Klusmeyer, T. H., A. C. Fitzgerald, A. C. Fabellar, J. M. Ballam, R. A. Cady, and J. L. Vicini. 2009. Effect of recombinant bovine somatotropin and a shortened or no dry period on the performance of lactating dairy cows. J. Dairy Sci. 92:5503-5511. https://doi .org/10.3168/jds.2009-2390.

Kremer, W. D., E. N. Noordhuizen-Stassen, F. J. Grommers, Y. H. Schukken, R. Heeringa, A. Brand, and C. Burvenich. 1993. Severity of experimental Escherichia coli mastitis in ketonemic and nonketonemic dairy cows. J. Dairy Sci. 76:3428-3436. https://doi .org/10.3168/jds.S0022-0302(93)77681-X.

Kuhn, M. T., J. L. Hutchison, and H. D. Norman. 2006. Effects of length of dry period on yields of milk fat and protein, fertility and milk somatic cell score in the subsequent lactation of dairy cows. J. Dairy Res. 73:154-162. https://doi.org/10.1017/ S0022029905001597.

Leslie, K. E., T. F. Duffield, Y. H. Schukken, and S. J. LeBlanc. 2000. The influence of negative energy balance on udder health. Pages 25-33 in Proc. Natl. Mastitis Council Regional Meetings, Madison, WI.

Mayasari, N., W. Rijks, G. de Vries Reilingh, G. J. Remmelink, B. Ducro, B. Kemp, H. K. Parmentier, and A. T. M. Van Knegsel. 2016. The effects of dry period length and dietary energy source on natural antibody titers and mammary health in dairy cows. Prev. Vet. Med. 127:1-9. https://doi.org/10.1016/j.prevetmed.2016.03.001.

NMC (National Mastitis Council). 1999. Laboratory Handbook on Bovine Mastitis. Rev. ed. NMC, Madison, WI

Olde Riekerink, R. G. M., H. W. Barkema, and H. Stryhn. 2007. The effect of season on somatic cell count and the incidence of clinical mastitis. J. Dairy Sci. 90:1704-1715. https://doi.org/10.3168/jds $.2006-567$.
Pantoja, J. C. F., C. Hulland, and P. L. Ruegg. 2009a. Dynamics of somatic cell counts and intramammary infections across the dry period. Prev. Vet. Med. 90:43-54. https://doi.org/10.1016/j .prevetmed.2009.03.012.

Pantoja, J. C. F., C. Hulland, and P. L. Ruegg. 2009b. Somatic cell count status across the dry period as a risk factor for the development of clinical mastitis in the subsequent lactation. J. Dairy Sci. 92:139-148.

Pezeshki, A., J. Mehrzad, G. R. Ghorbani, H. R. Rahmani, R. J. Collier, and C. Burvenich. 2007. Effects of short dry periods on performance and metabolic status in Holstein dairy cows. J. Dairy Sci. 90:5531-5541. https://doi.org/10.3168/jds.2007-0359.

Pinedo, P., C. Risco, and P. Melendez. 2011. A retrospective study on the association between different lengths of the dry period and subclinical mastitis, milk yield, reproductive performance, and culling in Chilean dairy cows. J. Dairy Sci. 94:106-115. https:// doi.org/10.3168/jds.2010-3141.

Rastani, R. R., R. R. Grummer, S. J. Bertics, A. Gümen, M. C. Wiltbank, D. G. Mashek, and M. C. Schwab. 2005. Reducing dry period length to simplify feeding transition cows: Milk production, energy balance, and metabolic profiles. J. Dairy Sci. 88:1004-1014. https://doi.org/10.3168/jds.S0022-0302(05)72768-5.

Reist, M., D. Erdin, D. von Euw, K. Tschuemperlin, H. Leuenberger, C. Delavaud, Y. Chilliard, H. M. Hammon, N. Kuenzi, and J. W. Blum. 2003. Concentrate feeding strategy in lactating dairy cows: Metabolic and endocrine changes with emphasis on leptin. J. Dairy Sci. 86:1690-1706. https://doi.org/10.3168/jds.S0022 -0302(03)73755-2.

Santschi, D. E., D. M. Lefebvre, R. I. Cue, C. L. Girard, and D. Pellerin. 2011. Incidence of metabolic disorders and reproductive performance following a short (35-d) or conventional (60-d) dry period management in commercial Holstein herds. J. Dairy Sci. 94:3322-3330. https://doi.org/10.3168/jds.2010-3595.

SAS Institute Inc. 2011. The SAS System for Windows. Release 9.3. SAS Institute Inc., Cary, NC.

Scherpenzeel, C. G., I. E. den Uijl, G. van Schaik, R. G. Olde Riekerink, J. M. Keurentjes, and T. J. G. M. Lam. 2014. Evaluation of the use of dry cow antibiotics in low somatic cell count cows. J. Dairy Sci. 97:3606-3614. https://doi.org/10.3168/jds.2013-7655.

Schlamberger, G., S. Wiedemann, E. Viturro, H. H. D. Meyer, and M. Kaske. 2010. Effects of continuous milking during the dry period or once daily milking in the first 4 weeks of lactation on metabolism and productivity of dairy cows. J. Dairy Sci. 93:2471-2485. https://doi.org/10.3168/jds.2009-2823.

Schukken, Y. H., D. J. Wilson, F. Welcome, L. Garrison-Tikofsky, and R. N. Gonzalez. 2003. Monitoring udder health and milk quality using somatic cell counts. Vet. Res. 34:579-596. https://doi.org/10 .1051/vetres:2003028.

Shoshani, E., S. Rozen, and J. J. Doekes. 2014. Effect of a short dry period on milk yield and content, colostrum quality, fertility, and metabolic status of Holstein cows. J. Dairy Sci. 97:2909-2922. https://doi.org/10.3168/jds.2013-7733.

Steeneveld, W., Y. H. Schukken, A. T. M. van Knegsel, and H. Hogeveen. 2013. Effect of different dry period lengths on milk production and somatic cell count in subsequent lactations in commercial Dutch dairy herds. J. Dairy Sci. 96:2988-3001. https://doi.org/10 $.3168 /$ jds.2012-6297.

Suriyasathaporn, W., C. Heuer, E. N. Noordhuizen-Stassen, and Y. H. Schukken. 2000. Hyperketonemia and the impairment of udder defense: A review. Vet. Res. 31:397-412.

Suthar, V. S., J. Canelas-Raposo, A. Deniz, and W. Heuwieser. 2013 Prevalence of subclinical ketosis and relationships with postpartum diseases in European dairy cows. J. Dairy Sci. 96:2925-2938. https://doi.org/10.3168/jds.2012-6035.

Tenhagen, B. A., G. Köster, J. Wallmann, and W. Heuwieser. 2006. Prevalence of mastitis pathogens and their resistance against antimicrobial agents in dairy cows in Brandenburg, Germany. J. Dairy Sci. 89:2542-2551. https://doi.org/10.3168/jds.S0022 -0302(06) 72330-X. 
van den Bogaard, A. E., and E. E. Stobberingh. 2000. Epidemiology of resistance to antibiotics. Int. J. Antimicrob. Agents 14:327-335. https://doi.org/10.1016/S0924-8579(00)00145-X.

Van Es, A. J. H. 1975. Feed evaluation for dairy cows. Livest. Prod. Sci. 40:95-107. https://doi.org/10.1016/0301-6226(75)90029-9.

van Hoeij, R. J., J. Dijkstra, R. M. Bruckmaier, J. J. Gross, T. J. Lam, G. J. Remmelink, B. Kemp, and A. T. M. van Knegsel. 2017a. The effect of dry period length and postpartum level of concentrate on energy balance and plasma metabolites of dairy cows across the dry period and in early lactation. J. Dairy Sci. 100:5863-5879. https://doi.org/10.3168/jds.2016-11703.

van Hoeij, R. J., J. Dijkstra, R. M. Bruckmaier, J. J. Gross, T. J. Lam, G. J. Remmelink, B. Kemp, and A. T. M. van Knegsel. 2017b. Consequences of dietary energy source and energy level on energy balance, lactogenic hormones and lactation curve characteristics of cows after a short or omitted dry period. J. Dairy Sci. 100:85448564. https://doi.org/10.3168/jds.2017-12855.

van Hoeij, R. J., T. J. Lam, D. B. De Koning, W. Steeneveld, B. Kemp, and A. T. M. van Knegsel. 2016. Cow characteristics and their association with udder health after different dry period lengths. J. Dairy Sci. 99:8330-8340. https://doi.org/10.3168/jds.2016-10901. van Knegsel, A. T. M., G. de Vries Reilingh, S. Meulenberg, H. van den Brand, J. Dijkstra, B. Kemp, and H. K. Parmentier. 2007. Natural antibodies related to energy balance in early lactation dairy cows. J. Dairy Sci. 90:5490-5498. https://doi.org/10.3168/ jds.2007-0289.

van Knegsel, A. T. M., G. J. Remmelink, S. Jorjong, V. Fievez, and B. Kemp. 2014. Effect of dry period length and dietary energy source on energy balance, milk yield, and milk composition of dairy cows. J. Dairy Sci. 97:1499-1512. https://doi.org/10.3168/jds.2013-7391.

Waage, S., S. Sviland, and S. A. Ødegaard. 1998. Identification of risk factors for clinical mastitis in dairy heifers. J. Dairy Sci. 81:12751284. https://doi.org/10.3168/jds.S0022-0302(98)75689-9.

Watters, R. D., J. N. Guenther, A. E. Brickner, R. R. Rastani, P. M. Crump, P. W. Clark, and R. R. Grummer. 2008. Effects of dry period length on milk production and health of dairy cattle. J. Dairy Sci. 91:2595-2603. https://doi.org/10.3168/jds.2007-0615.

Williamson, J. H., M. W. Woolford, and A. M. Day. 1995. The prophylactic effect of a dry-cow antibiotic against Streptococcus uberis. N. Z. Vet. J. 43:228-234. https://doi.org/10.1080/00480169.1995 .35898 